\title{
PERKEMBANGAN ARENA KAJIAN ANTROPOLOGI HUKUM
}

\author{
Tiara Putri Khairunisa \\ Email: tiaraputri040603@gmail.com \\ No.BP: 2110003600098 \\ Universitas EkaSakti Padang
}

\section{PENDAHULUAN}

Seorang filsuf China; Lao Chai, pernah berkata bahwa suatu perjalanan yang bermil-mil jauhnya dimulai dengan hanya satu langkah. Langkah manusia yang disebut filsuf itu tak lain adalah antropologi. Benda apa yang disebut dengan Antropologi itu? Beberapa atau bahkan banyak orang mungkin sudah pernah mendengarnya. Beberapa orang mungkin mempunyai ide-ide tentang Antropologi yang didapat melalui berbagai media baik media cetak maupun media elektronik. Beberapa orang lagi bahkan mungkin sudah pernah membaca literature-literature atau tulisan-tulisan tentang Antropologi.

Banyak orang berpikir bahwa para ahli Antropologi adalah ilmuwan yang hanya tertarik pada peninggalan-peninggalan masa lalu; Antroplogi bekerja menggali sisasisa kehidupan masa lalu untuk mendapatkan pecahan guci-guci tua, peralatan - peralatan dari batu dan kemudian mencoba memberi arti dari apa yang ditemukannya itu. Pandangan yang lain mengasosiasikan Antropologi dengan teori Evolusi dan mengenyampingkan kerja dari Sang Pencipta dalam mempelajari kemunculan dan perkembangan mahluk manusia. Masyarakat yang mempunyai pandangan yang sangat keras terhadap penciptaan manusia dari sudut agama kemudian melindungi bahkan melarang anak-anak mereka dari Antroplogi dan doktrin-doktrinnya. Bahkan masih banyak orang awam yang berpikir kalau Antropologi itu bekerja atau meneliti orangorang yang aneh dan eksotis yang tinggal di daerah-daerah yang jauh dimana mereka masih menjalankan kebiasaan-kebiasaan yang bagi masyarakat umum adalah asing.

Semua pandangan tentang ilmu Antroplogi ini pada tingkat tertentu ada benarnya, tetapi seperti ada cerita tentang beberapa orang buta yang ingin mengetahui bagaimana bentuk seekor gajah dimana masing-masing orang hanya meraba bagianbagian tertentu saja sehingga anggapan mereka tentang bentuk gajah itupun

menjadi bermacam-macam, terjadi juga pada Antropologi. Pandangan yang berdasarkan informasi yang sepotong-sepotong ini mengakibatkan kekurang pahaman masyarakat awam tentang apa sebenarnya Antropologi itu. Antropologi memang 
tertarik pada masa lampau. Mereka ingin tahu tentang asal-mula manusia dan perkembangannya, dan mereka juga mempelajari masyarakat-masyarakat yang masih sederhana (sering disebut dengan primitif). Tetapi sekarang Antropologi juga mempelajari tingkah-laku manusia di tempat-tempat umum seperti di restaurant, rumah-sakit dan di tempattempat bisnis modern lainnya. Mereka juga tertarik dengan bentuk-bentuk pemerintahan atau negara modern yang ada sekarang ini sama tertariknya ketika mereka mempelajari bentuk-bentuk pemerintahan yang sederhana yang terjadi pada masa lampau atau masih terjadi pada masyarakat-masyarakat di daerah yang terpencil.

\section{- Pengertian Antropologi}

Antropologi berasal dari kata anthropos yang berarti "manusia", dan logos yang berarti ilmu. Antropologi mempelajari manusia sebagai makhluk biologis sekaligus makhluk sosial, jadi antropologi adalah salah satu cabang ilmu pengetahuan sosial yang mempelajari tentang budaya masyarakat suatu etnis tertentu. Antropologi lahir atau muncul berawal dari ketertarikan orang-orang Eropa yang melihat ciri-ciri fisik, adat istiadat, budaya yang berbeda dari apa yang dikenal di Eropa. Terbentuklah ilmu antropologi dengan melalui beberapa fase. Antropologi lebih memusatkan pada penduduk yang merupakan masyarakat tunggal, tunggal dalam arti kesatuan masyarakat yang tinggal daerah yang sama, antropologi mirip seperti sosiologi tetapi pada sosiologi lebih menitik beratkan pada masyarakat dan kehidupan sosialnya.

Menurut William A. Haviland, antropologi adalah studi tentang umat manusia, berusaha menyusun generalisasi yang bermanfaat tentang manusia dan perilakunya serta untuk memperoleh pengertian yang lengkap tentang keanekaragaman manusia. Sedangkan David Hunter memberikan pendapatnya bahwa antropologi adalah ilmu yang lahir dari keingintahuan yang tidak terbatas tentang umat manusia. Selanjutnya Koentjaraningrat menyatakan antropologi adalah ilmu yang mempelajari umat manusia pada umumnya dengan mempelajari aneka warna, bentuk fisik masyarakat serta kebudayaan yang dihasilkan.

Dari definisi tersebut, dapat disusun pengertian sederhana antropologi, yaitu sebuah ilmu yang mempelajari manusia dari segi keanekaragaman fisik serta kebudayaan (cara-cara berprilaku, tradisi-tradisi, nilai-nilai) yang dihasilkan sehingga setiap manusia yang satu dengan yang lainnya berbeda-beda.

\section{- Pengertian Budaya}

Kebudayaan didefinisikan sebagai keseluruhan pengetahuan manusia sebagai makhluk sosial yang digunakannya untuk memahami dan menginterprestasikan 
lingkungan dan pengalamanya, serta menjadi landasan bagi tingkah-lakunya. Dengan demikian, kebudayaan merupakan serangkaian aturan-aturan, petunjuk-petunjuk, rencana-rencana, dan strategi-strategi yang terdiri atas serangkaian model-model kognitif yang dipunyai oleh manusia, dan digunakannya secara selektif dalam menghadapi lingkungannya sebagaimana terwujud dalam tingkah-laku dan tindakantindakannya.

Kebudayaan dapat didefinisikan sebagai suatu keseluruhan pengetahuan manusia sebagai makhluk sosial yang digunakan untuk memahami dan menginterpretasikan lingkungan dan pengalamannya, serta menjadi pedoman bagi tingkah lakunya.

Sebagai pengetahuan, kebudayaan adalah suatu satuan ide yang ada dalam kepala manusia dan bukan suatu gejala (yang terdiri atas kelakuan dan hasil kelakuan manusia). Sebagai satuan ide, kebudayaan terdiri atas serangkaian nilai-nilai, normanorma yang berisikan larangan-larangan untuk melakukan suatu tindakan dalam menghadapi suatu lingkungan sosial, kebudayaan, dan alam, serta berisi serangkaian konsep-konsep dan model-model pengetahuan mengenai berbagai tindakan dan tingkah laku yang seharusnya diwujudkan oleh pendukungnya dalam menghadapi suatu lingkungan sosial, kebudayaan, dan alam. Jadi nilai-nilai tersebut dalam penggunaannya adalah selektif sesuai dengan lingkungan yang dihadapi oleh pendukungnya.

Dari beberapa sisi, kebudayaan dapat dipandang sebagai: (1) Pengetahuan yang diyakini kebenarannya oleh masyarakat yang memiliki kebudayaan tersebut; (2) Kebudayaan adalah milik masyarakat manusia, bukan daerah atau tempat yang mempunyai kebudayaan tetapi manusialah yang mempunyai kebudayaan; (3) Sebagai pengetahuan yang diyakini kebenarannya, kebudayaan adalah pedoman menyeluruh yang mendalam dan mendasar bagi kehidupan masyarakat yang bersangkutan; (4) Sebagai pedoman bagi kehidupan, kebudayaan dibedakan dari kelakuan dan hasil kelakuan; karena kelakuan itu terwujud dengan mengacu atau berpedoman pada kebudayaan yang dipunyai oleh pelaku yang bersangkutan.

\section{- Hubungan Antropologi dan Budaya}

Kata Kebudayaan atau budaya adalah kata yang sering dikaitkan dengan Antropologi. Secara pasti, Antropologi tidak mempunyai hak eksklusif untuk menggunakan istilah ini. Seniman seperti penari atau pelukis juga memakai istilah ini atau diasosiasikan dengan istilah ini, bahkan pemerintah juga mempunyai departemen untuk ini. Konsep ini memang sangat sering digunakan oleh Antropologi dan telah 
tersebar kemasyarakat luas bahwa Antropologi bekerja atau meneliti apa yang sering disebut dengan kebudayaan. Seringnya istilah ini digunakan oleh Antropologi dalam pekerjaan-pekerjaannya bukan berarti para ahli Antropolgi mempunyai pengertian yang sama tentang istilah tersebut. Seorang Ahli Antropologi yang mencoba mengumpulkan definisi yang pernah dibuat mengatakan ada sekitar 160 defenisi kebudayaan yang dibuat oleh para ahli Antropologi. Tetapi dari sekian banyak definisi tersebut ada suatu persetujuan bersama diantara para ahli Antropologi tentang arti dari istilah tersebut. Salah satu definisi kebudayaan dalam Antropologi dibuat seorang ahli bernama Ralph Linton yang memberikan defenisi kebudayaan yang berbeda dengan pengertian kebudayaan dalam kehidupan sehari-hari: "Kebudayaan adalah seluruh cara kehidupan dari masyarakat dan tidak hanya mengenai sebagian tata cara hidup saja yang dianggap lebih tinggi dan lebih diinginkan".

Jadi, kebudayaan menunjuk pada berbagai aspek kehidupan. Istilah ini meliputi cara-cara berlaku, kepercayaan-kepercayaan dan sikap-sikap, dan juga hasil dari kegiatan manusia yang khas untuk suatu masyarakat atau kelompok penduduk tertentu.

Seperti semua konsep-konsep ilmiah, konsep kebudayaan berhubungan dengan beberapa aspek "di luar sana" yang hendak diteliti oleh seorang ilmuwan. Konsepkonsep kebudayaan yang dibuat membantu peneliti dalam melakukan pekerjaannya sehingga ia tahu apa yang harus dipelajari. Salah satu hal yang diperhatikan dalam penelitian Antropologi adalah perbedaan dan persamaan mahluk manusia dengan mahluk bukan manusia seperti simpanse atau orang-utan yang secara fisik banyak mempunyai kesamaan-kesamaan. Bagaimana konsep kebudayaan membantu dalam membandingkan mahluk-mahluk ini? Isu yang sangat penting disini adalah kemampuan belajar dari berbagai mahluk hidup. Lebah melakukan aktifitasnya hari demi hari, bulan demi bulan dan tahun demi tahun dalam bentuk yang sama. Setiap jenis lebah mempunyai pekerjaan yang khusus dan melakukan kegiatannya secara kontinyu tanpa memperdulikan perubahan lingkungan disekitarnya. Lebah pekerja terus sibuk mengumpulkan madu untuk koloninya. Tingkah laku ini sudah terprogram dalam gen mereka yang berubah secara sangat lambat dalam mengikuti perubahan lingkungan di sekitarnya. Perubahan tingkah laku lebah akhirnya harus menunggu perubahan dalam gen nya. Hasilnya adalah tingkah-laku lebah menjadi tidak fleksibel. Berbeda dengan manusia, tingkah laku manusia sangat fleksibel. Hal ini terjadi karena kemampuan yang luar biasa dari manusia untuk belajar dari pengalamannya. Benar bahwa manusia tidak terlalu istimewa dalam belajar karena mahluk lainnya pun ada yang mampu belajar, tetapi kemampuan belajar dari manusia sangat luar-biasa dan hal lain yang juga sangat penting adalah kemampuannya untuk beradaptasi dengan apa yang telah dipelajari itu. 


\section{PEMBAHASAN}

\section{A. Perkembangan Antropologi}

Seperti halnya Sosiologi, Antropologi sebagai sebuah ilmu juga mengalami tahapan-tahapan dalam perkembangannya. Koentjaraninggrat menyusun perkembangan ilmu Antropologi menjadi empat fase sebagai berikut:

1. Fase Pertama (Sebelum tahun 1800-an)

Sekitar abad ke-15-16, bangsa-bangsa di Eropa mulai berlomba-lomba untuk menjelajahi dunia. Mulai dari Afrika, Amerika, Asia, hingga ke Australia. Dalam penjelajahannya mereka banyak menemukan hal-hal baru. Mereka juga banyak menjumpai suku-suku yang asing bagi mereka. Kisah-kisah petualangan dan penemuan mereka kemudian mereka catat di buku harian ataupun jurnal perjalanan. Mereka mencatat segala sesuatu yang berhubungan dengan suku-suku asing tersebut. Mulai dari ciri-ciri fisik, kebudayaan, susunan masyarakat, atau bahasa dari suku tersebut. Bahan-bahan yang berisi tentang deskripsi suku asing tersebut kemudian dikenal dengan bahan etnogragfi atau deskripsi tentang bangsabangsa.

Bahan etnografi itu menarik perhatian pelajar-pelajar di Eropa. Kemudian, pada permulaan abad ke-19 perhatian bangsa Eropa terhadap bahan-bahan etnografi suku luar Eropa dari sudut pandang ilmiah, menjadi sangat besar. Karena itu, timbul usaha-usaha untuk mengintegrasikan seluruh himpunan bahan etnografi.

2. Fase Kedua (tahun 1800 -an)

Pada fase ini, bahan-bahan etnografi tersebut telah disusun menjadi karangankarangan berdasarkan cara berpikir evolusi masyarakat pada saat itu. masyarakat dan kebudayaan berevolusi secara perlahan-lahan dan dalam jangka waktu yang lama. Mereka menganggap bangsa-bangsa selain Eropa sebagai bangsa-bangsa primitif yang tertinggal, dan menganggap Eropa sebagai bangsa yang tinggi kebudayaannya

Pada fase ini, Antopologi bertujuan akademis, mereka mempelajari masyarakat dan kebudayaan primitif dengan maksud untuk memperoleh pemahaman tentang tingkat-tingkat sejarah penyebaran kebudayaan manusia.

3. Fase Ketiga (awal abad ke-20) 
Pada fase ini, negara-negara di Eropa berlomba-lomba membangun koloni di benua lain seperti Asia, Amerika, Australia dan Afrika. Dalam rangka membangun koloni-koloni tersebut, muncul berbagai kendala seperti serangan dari bangsa asli, pemberontakan-pemberontakan, cuaca yang kurang cocok bagi bangsa Eropa serta hambatan-hambatan lain. Dalam menghadapinya, pemerintahan kolonial negara Eropa berusaha mencari-cari kelemahan suku asli untuk kemudian menaklukannya. Untuk itulah mereka mulai mempelajari bahan-bahan etnografi tentang suku-suku bangsa di luar Eropa, mempelajari kebudayaan dan kebiasaannya, untuk kepentingan pemerintah kolonial.

4. Fase Keempat (setelah tahun 1930-an)

Pada fase ini, Antropologi berkembang secara pesat. Kebudayaan-kebudayaan suku bangsa asli yang di jajah bangsa Eropa, mulai hilang akibat terpengaruh kebudayaan bangsa Eropa.

Pada masa ini pula terjadi sebuah perang besar di Eropa, Perang Dunia II. Perang ini membawa banyak perubahan dalam kehidupan manusia dan membawa sebagian besar negara-negara di dunia kepada kehancuran total. Kehancuran itu menghasilkan kemiskinan, kesenjangan sosial, dan kesengsaraan yang tak berujung.

Namun pada saat itu juga, muncul semangat nasionalisme bangsa-bangsa yang dijajah Eropa untuk keluar dari belenggu penjajahan. Sebagian dari bangsa-bangsa tersebut berhasil mereka. Namun banyak masyarakatnya yang masih memendam dendam terhadap bangsa Eropa yang telah menjajah mereka selama bertahuntahun.

Proses-proses perubahan tersebut menyebabkan perhatian ilmu antropologi tidak lagi ditujukan kepada penduduk pedesaan di luar Eropa, tetapi juga kepada suku bangsa di daerah pedalaman Eropa seperti suku bangsa Soami, Flam dan Lapp.

Dalam kenyataannya, Antropologi mempelajari semua mahluk manusia yang pernah hidup pada semua waktu dan semua tempat yang ada di muka bumi ini. Mahluk manusia ini hanyalah satu dari sekian banyak bentuk mahluk hidup yang ada di bumi ini yang diperkirakan muncul lebih dari 4 milyar tahun yang lalu.

Antropologi bukanlah satu satunya ilmu yang mempelajari manusia. Ilmu-ilmu lain seperti ilmu Politik yang mempelajari kehidupan politik manusia, ilmu Ekonomi yang mempelajari ekonomi manusia atau ilmu Fisiologi yang mempelajari tubuh manusia dan masih banyak lagi ilmuilmu lain, juga mempelajari manusia. Tetapi ilmuilmu ini tidak mempelajari atau melihat manusia secara menyeluruh atau dalam ilmu 
Antropologi disebut dengan Holistik, seperti yang dilakukan oleh Antropologi. Antropologi berusaha untuk melihat segala aspek dari diri mahluk manusia pada semua waktu dan di semua tempat, seperti: Apa yang secara umum dimiliki oleh semua manusia? Dalam hal apa saja mereka itu berbeda? Mengapa mereka bertingkahlaku seperti itu? Ini semua adalah beberapa contoh pertanyaan mendasar dalam studistudi Antropologi.

\section{B. Antropologi Sosial-Budaya}

Antropologi Sosial-Budaya atau lebih sering disebut Antropologi Budaya berhubungan dengan apa yang sering disebut dengan Etnologi. Ilmu ini mempelajari tingkah-laku manusia, baik itu tingkah-laku individu atau tingkah laku kelompok. Tingkah-laku yang dipelajari disini bukan hanya kegiatan yang bisa diamati dengan mata saja, tetapi juga apa yang ada dalam pikiran mereka. Pada manusia, tingkah-laku ini tergantung pada proses pembelajaran. Apa yang mereka lakukan adalah hasil dari proses belajar yang dilakukan oleh manusia sepanjang hidupnya disadari atau tidak. Mereka mempelajari bagaimana bertingkah-laku ini dengan cara mencontoh atau belajar dari generasi diatasnya dan juga dari lingkungan alam dan sosial yang ada disekelilingnya. Inilah yang oleh para ahli Antropologi disebut dengan kebudayaan. Kebudayaan dari kelompok-kelompok manusia, baik itu kelompok kecil maupun kelompok yang sangat besar inilah yang menjadi objek spesial dari penelitianpenelitian Antropologi Sosial Budaya. Dalam perkembangannya Antropologi SosialBudaya ini memecah lagi kedalam bentuk-bentuk spesialisasi atau pengkhususan disesuaikan dengan bidang kajian yang dipelajari atau diteliti. Antroplogi Hukum yang mempelajari bentuk-bentuk hukum pada kelompokkelompok masyarakat atau Antropologi Ekonomi yang mempelajari gejala-gejala serta bentuk-bentuk perekonomian pada kelompok-kelompok masyarakat adalah dua contoh dari sekian banyak bentuk spesialasi dalam Antropologi Sosial-Budaya.

Kebudayaan yang dimiliki oleh manusia juga dimiliki dengan cara belajar. Dia tidak diturunkan secara bilogis atau pewarisan melalui unsur genetis. Hal ini perlu ditegaskan untuk membedakan perilaku manusia yang digerakan oleh kebudayaan dengan perilaku mahluk lain yang tingkah-lakunya digerakan oleh insting.

Ketika baru dilahirkan, semua tingkah laku manusia yang baru lahir tersebut digerakkan olen insting dan naluri. Insting atau naluri ini tidak termasuk dalam kebudayaan, tetapi mempengaruhi kebudayaan. Contohnya adalah kebutuhan akan makan. Makan adalah kebutuhan dasar yang tidak termasuk dalam kebudayaan. Tetapi bagaimana kebutuhan itu dipenuhi; apa yang dimakan, bagaimana cara memakan adalah bagian dari kebudayaan. Semua manusia perlu makan, tetapi kebudayaan yang 
berbeda dari kelompok-kelompoknya menyebabkan manusia melakukan kegiatan dasar itu dengan cara yang berbeda. Contohnya adalah cara makan yang berlaku sekarang. Pada masa dulu orang makan hanya dengan menggunakan tangannya saja, langsung menyuapkan makanan kedalam mulutnya, tetapi cara tersebut perlahan lahan berubah, manusia mulai menggunakan alat yang sederhana dari kayu untuk menyendok dan menyuapkan makanannya dan sekarang alat tersebut dibuat dari banyak bahan. Begitu juga tempat dimana manusia itu makan. Dulu manusia makan disembarang tempat, tetapi sekarang ada tempat-tempat khusus dimana makanan itu dimakan. Hal ini semua terjadi karena manusia mempelajari atau mencontoh sesuatu yang dilakukan oleh generasi sebelumya atau lingkungan disekitarnya yang dianggap baik dan berguna dalam hidupnya.

Sebaliknya kelakuan yang didorong oleh insting tidak dipelajari. Semut semut yang dikatakan bersifat sosial tidak dikatakan memiliki kebudayaan, walaupun mereka mempunyai tingkah-laku yang teratur. Mereka membagi pekerjaannya, membuat sarang dan mempunyai pasukan penyerbu yang semuanya dilakukan tanpa pernah diajari atau tanpa pernah meniru dari semut yang lain. Pola kelakuan seperti ini diwarisi secara genetis.

\section{Pengaruh Budaya Dalam Perkembangan Antropologi}

Agar dapat dikatakan sebagai suatu kebudayaan, kebiasaan-kebiasaan seorang individu harus dimiliki bersama oleh suatu kelompok manusia. Para ahli Antropologi membatasi diri untuk berpendapat suatu kelompok mempunyai kebudayaan jika para warganya memiliki secara bersama sejumlah pola-pola berpikir dan berkelakuan yang sama yang didapat melalui proses belajar.

Suatu kebudayaan dapat dirumuskan sebagai seperangkat kepercayaan, nilainilai dan cara berlaku atau kebiasaan yang dipelajari dan yang dimiliki bersama oleh para warga dari suatu kelompok masyarakat. Pengertian masyarakat sendiri dalam Antropologi adalah sekelompok orang yang tinggal di suatu wilayah dan yang memakai suatu bahasa yang biasanya tidak dimengerti oleh penduduk tetangganya.

Dalam setiap masyarakat, oleh para anggotanya dikembangkan sejumlah polapola budaya yang ideal dan pola-pola ini cenderung diperkuat dengan adanya pembatasanpembatasan kebudayaan. Pola-pola kebudayaan yang ideal itu memuat hal-hal yang oleh sebagian besar dari masyarakat tersebut diakui sebagai kewajiban yang harus dilakukan dalam keadaan-keadaan tertentu. Pola-pola inilah yang sering disebut dengan norma-norma, Walaupun kita semua tahu bahwa tidak semua orang dalam kebudayaannya selalu berbuat seperti apa yang telah mereka patokkan bersama sebagai 
hal yang ideal tersebut. Sebab bila para warga masyarakat selalu mematuhi dan mengikuti norma-norma yang ada pada masyarakatnya maka tidak akan ada apa yang disebut dengan pembatasan-pembatasan kebudayaan.

\section{PENUTUP}

\section{A. Kesimpulan}

Antropologi adalah salah satu cabang ilmu pengetahuan sosial yang mempelajari tentang budaya masyarakat suatu etnis tertentu. Antropologi lahir atau muncul berawal dari ketertarikan orang-orang Eropa yang melihat ciri-ciri fisik, adat istiadat, budaya yang berbeda dari apa yang dikenal di Eropa. Terbentuklah ilmu antropologi dengan melalui beberapa fase. Antropologi lebih memusatkan pada penduduk yang merupakan masyarakat tunggal, tunggal dalam arti kesatuan masyarakat yang tinggal daerah yang sama, antropologi mirip seperti sosiologi tetapi pada sosiologi lebih menitik beratkan pada masyarakat dan kehidupan sosialnya. Perkembangan antropologi terdiri atas 4 tahap yaitu ; 1)

O Fase Pertama (Sebelum tahun 1800-an)

Sekitar abad ke-15-16, bangsa-bangsa di Eropa mulai berlomba-lomba untuk menjelajahi dunia. Mulai dari Afrika, Amerika, Asia, hingga ke Australia. Dalam penjelajahannya mereka banyak menemukan hal-hal baru. Mereka juga banyak menjumpai suku-suku yang asing bagi mereka. Kisah-kisah petualangan dan penemuan mereka kemudian mereka catat di buku harian ataupun jurnal perjalanan.

O Fase Kedua (tahun 1800-an)

Pada fase ini, bahan-bahan etnografi tersebut telah disusun menjadi karangankarangan berdasarkan cara berpikir evolusi masyarakat pada saat itu. masyarakat dan kebudayaan berevolusi secara perlahan-lahan dan dalam jangka waktu yang lama. Mereka menganggap bangsa-bangsa selain Eropa sebagai bangsa-bangsa primitif yang tertinggal, dan menganggap Eropa sebagai bangsa yang tinggi kebudayaannya

O Fase Ketiga (awal abad ke-20) 
Pada fase ini, negara-negara di Eropa berlomba-lomba membangun koloni di benua lain seperti Asia, Amerika, Australia dan Afrika. Dalam rangka membangun koloni-koloni tersebut, muncul berbagai kendala seperti serangan dari bangsa asli, pemberontakan-pemberontakan, cuaca yang kurang cocok bagi bangsa Eropa serta hambatan-hambatan lain.

O Fase Keempat (setelah tahun 1930-an)

Pada fase ini, Antropologi berkembang secara pesat. Kebudayaan-kebudayaan suku bangsa asli yang dijajah bangsa Eropa, mulai hilang akibat terpengaruh kebudayaan bangsa Eropa. 


\section{DAFTAR PUSTAKA}

Laurensius Arliman S, Peran Badan Permusyawaratan Desa di Dalam Pembangunan Desa dan Pengawasan Keuangan Desa, Padjadjaran Journal of Law, Volume 4, Nomor 3, 2017. https://doi.org/10.15408/jch.v4i2.3433.

Laurensius Arliman S, Penanaman Modal Asing Di Sumatera Barat Berdasarkan Undang- Undang Nomor 25 Tahun 2007 Tentang Penanaman Modal, Supremasi

Hukum, Volume 1, Nomor 1, 2018. http://dx.doi.org/10.36441/hukum.v1i01.102.

Laurensius Arliman S, Memperkuat Kearifan Lokal Untuk Menangkal Intoleransi Umat Beragama Di Indonesia, Ensiklopedia of Journal, Volume 1, Nomor 1, 2018, https://doi.org/10.33559/eoj.v1i1.18.

Laurensius Arliman S, Perkawinan Antar Negara Di Indonesia Berdasarkan Hukum Perdata Internasional, Kertha Patrika, Volume 39, Nomor 3, 2017, https://doi.org/10.24843/KP.2017.v39.i03.p03.

Laurensius Arliman S, Partisipasi Masyarakat Di Dalam Pengelolaan Uang Desa Pasca Undang-Undang Nomor 6 Tahun 2014 Tentang Desa, Jurnal Arena Hukum, Volume 12, Nomor 2, 2019, https://doi.org/10.21776/ub.arenahukum.2019.01202.5.

Laurensius Arliman S, Mewujudkan Penegakan Hukum Yang Baik Di Negara Hukum Indonesia, Dialogica Jurnalica, Volume 11, Nomor 1, 2019, https://doi.org/10.28932/di.v11i1.1831.

Laurensius Arliman S, Mediasi Melalui Pendekatan Mufakat Sebagai Lembaga Alternatif Penyelesaian Sengketa Untuk Mendukung Pembangunan Ekonomi Nasional, UIR Law Review, Volume 2, Nomor 2, 2018, https://doi.org/10.25299/uirlrev.2018.vol2(02).1587

Laurensius Arliman S, Peranan Filsafat Hukum Dalam Perlindungan Hak Anak Yang Berkelanjutan Sebagai Bagian Dari Hak Asasi Manusia, Doctrinal, Volume 1, Nomor 2, 2016.

Laurensius Arliman S, Ni Putu Eka Dewi, Protection of Children and Women's Rights in Indonesia through International Regulation Ratification, Journal of Innovation, Creativity and Change Volume 15, Nomor 6, 2021.

Laurensius Arliman S, Gagalnya Perlindungan Anak Sebagai Salah Satu Bagian Dari Hak Asasi Manusia Oleh Orang Tua Ditinjau Dari Mazhab Utilitarianisme, Jurnal Yuridis, Volume 3, Nomor 2, 2016, http://dx.doi.org/10.35586/.v3i2.180.

Laurensius Arliman S, Tantangan Pendidikan Kewarganegaraan Pada Revolusi 4.0, Jurnal Ensiklopedia Sosial Review, Volume 2, Nomor 3, $2020 .$. 
